Journal of Southeast Asian

\title{
Appendix E: Focus Group Summary of the Lao College Students at the University of California, San Diego
}

Samly Maat

Lao Parent Student Teacher Association in San Diego, samly@cox.net

Follow this and additional works at: https://docs.lib.purdue.edu/jsaaea

\section{Recommended Citation}

Maat, Samly (2011) "Appendix E: Focus Group Summary of the Lao College Students at the University of California, San Diego," Journal of Southeast Asian American Education and Advancement: Vol. 6 : Iss. 1 , Article 6.

DOI: $10.7771 / 2153-8999.1022$

Available at: https://docs.lib.purdue.edu/jsaaea/vol6/iss1/6

This document has been made available through Purdue e-Pubs, a service of the Purdue University Libraries. Please contact epubs@purdue.edu for additional information.

This is an Open Access journal. This means that it uses a funding model that does not charge readers or their institutions for access. Readers may freely read, download, copy, distribute, print, search, or link to the full texts of articles. This journal is covered under the CC BY-NC-ND license. 


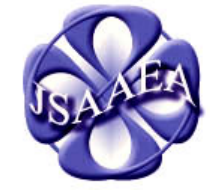

Volume 6 (2011)
Journal of Southeast Asian American

Education \& Advancement

WWW.JSAAEA.org
A peer-reviewed
Southeast Asian American Education 35 Years After Initial Resettlement: Research Report and Policy Recommendations

Conference Report of the National Association for the Education and Advancement of Cambodian, Laotian, and Vietnamese Americans

\title{
APPENDIX E
}

\section{Focus Group Summary of the Lao College Students at the University of California, San Diego}

\author{
Dr. Samly Maat \\ Lao Parent-Student-Teacher Association in San Diego
}

\section{Focus Group Discussion Topics}

The topic for this Lao college student focus group was K-12: Access, Assessment and accountability. Some of the questions asked were selected from the guideline list provided by NAFEA.

\section{Participants}

Only four Lao college students from University of California, San Diego (UCSD) participated in this focus group session. However, the group had a good mix. Two students were at their last year of college. They both were the first-generation refugees. They entered the U.S. at their young age. The other two students were in their first year of college and they were the second-generation refugees. All four students attended the inner city K-12.

The general themes from the discussion were strongly agreed by participants of this focus group. The main themes discussed are categorized as following.

\footnotetext{
@ SORERIIGHISRESEREED Readers are free to copy, display, and distribute this article, as long as the work is attributed to the author(s) and the Journal of Southeast Asian American Education \& Advancement, it is distributed for noncommercial purposes only, and no alteration or transformation is made in the work. More details of this Creative Commons license are available at http://creativecommons.org/licenses/by-nc-nd/3.0/. All other uses must be approved by the author(s) or JSAAEA.
} 


\section{Parents and Family Members}

Parents and other family members are significant factors on the students' success in school. All four students agreed that their parents were not helpful with their school or schoolwork.

One student said, "I wish my parents were involved in my school activities but I understood why they didn't. They didn't know anything about my school or homework. They couldn't help me with my homework anyway."

Other student said, "I wish my parents were more strict with me when comes to homework. They may ask if I had home but they didn't check if I told the truth or not. But, I can't blame them. They can't understand anything any way."

All four students agreed that their parents made home chores their first priority, not their homework. However, they appeared to understand their parents' actions due to the parents' limited education and English speaking ability in addition to their daily struggle to provide for the family.

\section{Schools (K-12)}

Students also agreed that their schools were at poor quality. In fact, they believed their community and schools were inferior in their surrounding environments, equipments, and supplies. Nevertheless, students appeared to understand their schools for not having enough funds to improve the conditions. Both second-generation students claimed that with the fund school had, it was misused. One said, "Why math classes needs big screen TVs? That, I don't understand. That money could have been used to buy better teaching equipments."

All students agreed that there were no Lao teachers or faculties at their schools. One said, "Even if there were Lao teachers or faculties that wouldn't make a difference in their learning ability." Other student agreed. They appeared to be careless about the gender or race of the teachers. They agreed that teachers didn't need to know the students culture but they wish their teachers understood their life challenges at home or outside school.

There was one interesting thing a student said about a new program at his school called AVID (Advance Via Individual Determination). A student explained that this program helped him get motivated and inspired to stay in school and continuing to college. Without this program, he wouldn't know what to do to get into a college. One of the requirements to stay in this program was to hold at least a $\mathrm{C}$ grade average. He said, even then, it was not easy for his friends to participate in the program.

All students were neutral on the state standard tests. They didn't think those tests accurately measure they knowledge but understood that the government needed some data to show school's performance. One student said, "We spent a whole week preparing for the tests. If we do good, we can some kind of awards, like some money or treats." 


\section{Friends}

All students strongly agreed that the type of friends they hang out with could greatly influence who they are. All four students also agreed that many of their Lao friends quit school. One said, "My friends joined gang because they don't believe that education will help them. No one cares anyway. And, they parents can't help them anyway."

When asked what made them stay in school while their friends quit or joined gang, students provided different answers. However, when sum it all up, they concurred that believing in self-worth and understanding the value of education were the two important factors for them to have.

One student said, "Staying in school is the only natural thing for me. My parents made me do it. I had no choice.” That's what all students should feel.

The other said, "My family is helpless, I need to help them." With his sad voice, he said, "My sister didn't finish high school. She's now trying to raise a child with no job and trying to attend vocational school. I have four more siblings. My parents can't do anything to help us. I know I have to take care of my family. This is why I stayed in school and continued here to college. Many of my friends dropped out of school and joined some gangs or just hang out. But, they are still my friends."

\section{College}

Both college freshmen said they are struggle. They implied that their high school did not prepare them enough for college level courses. Not only having to deal with the college life; but also, they have to deal with academic challenges because their level of education is not up to the college level standard. They wished their teachers had provided more challenge class materials and be stricter with their performance.

They didn't see other Lao students on the campus. One student believed that there are only Lao students in UCSD. The other said, "In my whole college, I think I am the only Lao student. It is very sad."

\section{Government}

When asked what the government can do to assist students in staying in school and do well, both second-generation students agreed that government should show more concerns to all schools, not just the ones on the better side or rich side of the town.

Once said, "One time the governor visited the school on the good side of the town but not our school. I felt left out, abundant, and unworthy for the government to visit us." One said, his friends often complaint that, "They don't care about us, why should we care?"

\section{Community or Community Leaders}

Students didn't believe their community or community leaders can help them. Students agreed that the communities are struggling as they are. 
All students agreed that the temples don't have activities specially for children. They wished there were something that's for them to do at the temples. They went to the temples because their parents made them. However, one student said, "We go to the temple. We respect the monks, as we have been taught to do so. We obeyed when the monks asked us to do something, even if we don't want to do it. This is because we respect them."

One thing was shocking to hear was when one of the students said, "What community leaders? I don't think I saw any of them in my community." More than 30 years now that we have been in the United States, some of our children still don't know their community leaders who have been trying to improve the community.

\section{Student Leader's Comments}

We, as parents, leaders, teachers, and community leaders, can make great impact to our youth during students' K-12 years. By the time college age comes, the chance to make them go and stay in college is nearly impossible. The value of education needs to be ingrained in their heads before it is too late. Self-worth or high self-esteem must be instilled in their hearts and souls starting from the very young age.

Although, there is no one silver bullet solution, making children's homes, schools, and environments induce to learning is a critical part in keeping them in school and continue to pursue higher education. All of us must work together. Parents, friends, community, and government all need to work together. We need more people in the field actively involved with the families, in schools, and communities.

We can provide all the programs, all high tech equipments, and all fancy playgrounds but if our children don't understand the purposes or don't use the provided resources, the resources are useless to our youth. We need to build capacity and self-esteem in our children. They need to be taught and understand that they are gifted and worthy of good life - not just those students who were born into the good side of town.

\section{About the Author}

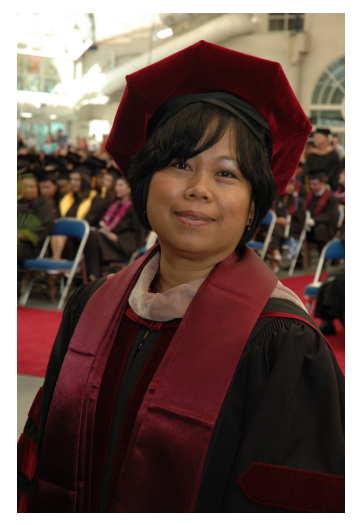

Dr. Samly Maat holds a Doctor Degree of Management in Organizational Leadership from the University of Phoenix. Since November of 2005, Dr. Maat has been involved with the Lao community in San Diego, CA and Rochester, NY. Her life long study is deep-rooted from her greatest desire to help improve Lao community and thus the society as a whole. Dr. Maat has worked in the software development industry for over 18 years, holding a variety of positions in the Information System/Technology sector. She volunteers at various community service organizations including the Lao PSTA, the Character Building Committee of the Santee School District; the Lincoln High School Transition Team; and the Lao American Scholarship Foundation. She is also the Lao American Community Member Representative for the San Diego School Board. 